\title{
DID SHAKESPEARE OWE ANYTHING TO SENECA? THE DEBATE OUTLINED
}

\author{
M Frank (University of the Witwatersrand)
}

The importance of Seneca for Elizabethan drama, specifically Shakespeare, is one of the things that classicists tend to point to (along with the Greek roots of western democracy, the widespread influence of Roman law, the literary importance of classical mythology, etc.), when, as the poor relations in Arts Faculties, they feel the need to justify their existence. Having done this myself for some years, I came to realize that I had very little idea of how Seneca was important, why he was important, and even whether he was really important at all.

My aim here is a very modest one-to draw to the attention of classicists, and to shine a little critical light on, the long-standing and sometimes heated debate about the nature and extent of Senecan influence on English tragedy of the Elizabethan period and on Shakespeare in particular.

One has, inevitably, to start with the old question of whether Shakespeare would have known Latin well enough to read Seneca in the original. The arguments about this form a separate debate, one in which, as Charles Martindale said, "All too often one can hear the sound of the grinding of axes" (Martindale 1990:4). Particularly in the eighteenth century, some readers felt that the honour of England demanded that Shakespeare be shown to be steeped in classical learning, whereas others felt that the fact that he did not have a strong classical education was proof of his natural greatness. In this century, the Leavis school's agenda of establishing English as a discipline separate from Classics from which it had arisen, involved what Martindale calls, "the perverse privileging of the supposedly 'native' over any foreign influences" (Martindale 1990:5). This meant that Milton was "out" and Shakespeare was "in", but a Shakespeare who was the descendent of a proud native dramatic tradition, untainted by the classics. ${ }^{1}$

The first well-known reference to Shakespeare's classical learning is Ben Jonson's famous comment of 1623 to the effect that Shakespeare had "small Latin and less Greek" (Jonson 1623:line 31). This comment was intended to exalt Shakepeare, not to denigrate him: Jonson used the phrase in the context of expressing his admiration of the fact that, although Shakepeare had little classical learning, he surpassed (in Jonson's opinion) not only all previous English poets but also all classical writers of tragedy and comedy. A great deal of scholarly attention has been devoted to trying to establish the nature of Shakespeare's education, what his school curriculum consisted of (he did not go to university), and how competent

We are, of course, no strangers to this process of perverse privileging in the 1990's: in Departments of English in the United States, Shakespeare (perceived as white, male and Eurocentric) is being increasingly marginalized to make way for native and more politically correct texts. 
in Latin he would have been. T W Baldwin in his monumental two-volume work, William Shakespeare's Small Latine and Lesse Greeke (Urbana, Illinois, 1944), has established that the classical knowledge which Shakepeare's plays reveal is completely consonant with a grammar school education of the time. It would appear, then, that Shakepeare's Latin should be regarded as "small" only by comparison with Jonson's own-by twentieth-century school standards it would have been large and, significantly, highly rhetorical (Whitaker 1969:27-35). It is unlikely that Shakepeare read Seneca's tragedies at school (Baldwin 1944:1.197), but it seems clear that he was competent to do so, perhaps with the aid of a translation. Translations of Seneca's tragedies in English appeared one by one from 1559 onward and a collected translation of the plays was published in 1581 , but these translations failed to capture the nature of Senecan rhetoric. They have been described as "totally incapable of sharpness or compression; the hobnailed violence of their vocabulary is without self-conscious capacity for variation.... [T] he sophistication (even decadence) of his [i.e. Seneca's] repetitive cleverness seems outside the range of their language" (Hunter 1974:187). When one considers the un-Senecan style of the translations and the presence of Senecan rhetoric in Shakespeare, it is difficult to avoid the conclusion that Shakespeare must have read at least some Seneca in the original. ${ }^{2}$

So Shakepeare owed something to Seneca at least in terms of rhetoric. Was his influence limited to this? At this point we enter the debate proper.

In 1893 John Cunliffe declared with conviction: "The influence of Seneca ... upon the Elizabethan drama is so plainly marked that no competent historian of our literature could fail to notice it" (Cunliffe 1965:1). And, in terms unflattering to both Seneca and the Elizabethans, but with no less conviction, Evelyn Spearing in 1912 said fastidiously: "The Senecan drama, crude and melodramatic as it seems to us, appealed far more strongly to the robust Englishmen of the sixteenth century, whose animal instincts were as yet only half subdued by civilization" (1912:1).

Cunliffe's view of Senecan tragedy as being the supreme influence on Elizabethan tragedy was the orthodox view for many years and was not seriously challenged until 1939 by Howard Baker. Interestingly, Baker's attack on the notion of Senecan influence-he found native precedents for features of Elizabethan plays that had been regarded as Senecan-was almost entirely ignored by scholars, who continued to follow faithfully the position established by Cunliffe and bolstered by two generations of scholars after him. ${ }^{3}$

2 Miola (1992:1) observes that "by the time of Hamlet there existed over fifty printings of the collected tragedies in various editions."

3 See, for example, the extravagant claims for Senecan influence made by Charlton (1974:clxix): “Above all, Seneca ... was their greatest storehouse of tragic material. He provided the most tragic motive, revenge exacted on the closest consanguinity. He provided the most tragic theme, the inevitability of Fate's decrees. He provided the most tragic appeal, horror piling itself on horror. He provideed the most tragic machinery, ghosts, supernatural forces, and foreboding dreams; the most tragic incidents, murder inflicted in the most cruel and most bloodthirsty way. He provided the most tragic characters, superhuman villains dominated with one abnormal consuming passion. He provided the most tragic sentiment, morbid introspective self-pity and self-reliance. He provided the superlative tragic style, whether for the utterance of passion, 
It was not until the 1960's that Seneca's position as the single overriding influence on Elizabethan tragedy was seriously challenged. The challenge came from G.K. Hunter, Professor of English Literature at Yale University. In an article entitled "Seneca and the Elizabethans: A case-study in influence" (Hunter 1967:1726) he vigorously attacked Cunliffe's methodology, which, predictably enough for the period, centered on the listing of parallel passages. He pointed out, fairly damningly, that Cunliffe largely bases his thesis on one uninfluential play, Thomas Hughes' The Misfortunes of Arthur (1587), from which most of his parallel passages are taken. He noted, too, that Cunliffe's method, which works so well for this play and for one or two others, does not work at all for the plays of Shakespeare (which is something of an exaggeration). He also demolished the assumption of Cunliffe and his disciples that the vernacular tradition had nothing positive to offer and that consequently "in the main, the Renaissance served up classical tragedy on a tabula rasa" (Hunter 1967:19). Hunter stressed the eclectic nature of influence, but argued that the ancestry of the developed popular drama went back to the informal Tudor interludes and to mediaeval drama, with Seneca barely involved at all. Seneca's ghostly apparitions, tyrants, violence, and ranting could, he justly maintained, as well be found in the native dramatic tradition (the mediaeval plays dealing with the lives and deaths of saints contain plenty of horrors). Even the five-act structure came from Terence and not from Seneca (Hunter 1967:21). He concluded that "We are left with a few well-wom anthology passages and a few isolated tricks like stichomythia (and even that occurs outside tragedy) as relics of the once extensive empire of Seneca's undisputed influence" (Hunter 1967:21).

Hunter followed up the attack in 1974 with an essay entitled "Seneca and English Tragedy" (1974:166-204), in which he drew attention to the Christian ethos of Shakespearian tragedy, stressing that the fundamental ethical assumptions of Seneca's plays are profoundly different from the Elizabethan plays they are supposed to have influenced.

Hunter's papers have been extremely influential and a valuable corrective both to the methodolgy employed by the pro-Senecans and to the Cunliffian view of the development of tragedy which ignored the non-classical literary tradition completely. They are interesting also in that they reflect the development in the understanding of the complexities of literary influence and the anti-classicizing tendencies of English scholars since the 1960's. Their style is both trenchant and authoritative.

Although valuable, Hunter's essays exemplify the inevitable movement of the proverbial pendulum. In his determination to dissociate the Elizabethan dramatists from the influence of Seneca, he plays down the fact that theirs was a classicizing

picture, or sentence." For an survey of the scholarship up to 1977, see Kiefer 1978:17-34; a supplement published in 1985 takes the account up to 1984. 
age $^{4}$ and that imitatio (the conscious reworking of texts to form a new literary creation) was the informing principle of Renaissance thinking about literature. Nor does he connect these two facts with the admiration of the Elizabethans for the style of Senecan drama which he concedes (Hunter 1974:187). Indeed, literary critics of the time seem to have been much more interested in the style than in the content of Seneca's plays. Sir Philip Sydney, for example, praised The Tragedy of Gorboduc, first published in 1562 and historically significant as the first regular English tragedy and the first English play to be written almost entirely in blank verse, for "clyming to the height of Seneca his style" (Feuillerat 1923:38). The Elizabethans did not disparage Senecan drama, partly, no doubt, because, unlike Hunter (and many modern classicists), they were not always looking over their shoulders at the tragedies of the great Attic triad. ${ }^{5}$ And even when they were, a scholar as eminent as Julius Caesar Scaliger appreciated Seneca's style and referred to him as one

whom I judge to be inferior to none of the Greeks in majesty: in ornaments of style and in elegance greater even than Euripides. The plots certainly are theirs, but the majesty, the sound, and the spirit of the poetry are his own. ${ }^{6}$

There is no doubt that the Elizabethans positively admired the flamboyant baroqueness of Seneca, a fact that often seems to embarrass modern scholars who appear to see it as an inexplicable breach of good taste.

The first Senecan tragedy was performed at Trinity College, Cambridge in 1551-1552. Then there was a gap until 1559 , when not only did the translations of individual plays begin to appear, but the plays began to be performed frequently and direct imitations of them were also produced (Charlton 1974:cxl-cxli). One of these was Gorboduc, which has already been mentioned as the first English tragedy: one might also describe it as the first Senecan tragedy in English.

4 Charles and Michelle Martindale (1990:30) suggest that the gap between the Tudor interludes and the developed drama of the Renaissance is "partly the result of a more precise use of classical models including Seneca, and the ability to transfer into the vernacular aspects of their styles. From the early sixteenth century onwards classical influences were at work even in popular entertainments."

5 As Charles and Michelle Martindale observe (1990:41-42), "Renaissance culture remained primarily Latin-based; significantly Sidney was advised that Greek was not a vital study. If Shakespeare read any Greek plays, he will thus have read them in Latin (there were no published English translations except Jocasta [this, in any case, was an Italian adaptation; see Cunliffe 1965:9], although Peele apparently translated an Iphigeneia). ... One cannot help feeling that the search for direct connections with Greek drama springs from the desire to draw together the two supreme tragic traditions, and from a dissatisfaction with the single influence of Seneca, a dissatisfaction compounded by the narrow and prescriptive attitudes of most classical scholars towards him." See Costa 1975:33-41 for the opinions of other critics of the time; also Martindale 1990:33-34 and Miola 1992:1-2.

6 "Seneca ... quem nullo Graecorum maiestate inferiore existimo: cultu vero ac nitore etiam Euripide maiorem. Inventiones sane illorum sunt: at maiestas carminis, sonus, spiritus ipsius" (1561:323). 
Hunter's argument that Senecan influence on Elizabethan drama consists only of "a few well-worn anthology passsages" ignores the fact that there are significant echoes of Seneca in Shakespeare's tragedies which do not appear in the anthologies, and suggests, as Miola observes, that verbal reminiscence is the only evidence of influence (Miola 1992:5). While critical of Cunliffe's methodology, Hunter seems himself to be somewhat bound by it. And his very qualified concession that the stichomythia in Shakespeare may owe something to Seneca is indicative of his general reluctance to concede any influence to the classics. In a note he claims that "there seems to be a largely comic tradition of this [i.e. stichomythia] in English drama, quite independent of classical models" (Hunter 1967:167n2). The examples he gives, however, are much less like Senecan stichomythia than are Shakespeare's. Senecan stichomythic exchanges are characterised by their swiftness, their polemical nature-the aim of the speakers not to impart information but to score points-and by the high incidence of antilabe over one line exchanges. The dialogue proceeds through verbal echo, sometimes with revision of meaning. These exchanges also tend to be highly gnomic (Tarrant 1985:120). All these features can be found in Shakespeare but not in mediaeval drama or in the Tudor interludes.

That Hunter threw a large pebble into the complacent waters of Senecan dominance is undoubted. However, he has not succeeded in convincing scholars that "the once extensive empire of Seneca's undisputed influence" should be reduced virtually to nothing. This is indicated by the fact that several books have appeared since the publication of Hunter's essays ${ }^{7}$ which reassert different aspects of the influence of Senecan drama on Elizabethan tragedy.

What Hunter's essays did do, however, was to steer the study of Senecan influence into more imaginative and diverse channels. His attack on Senecan influence, coupled with the new understanding of the complexity of literary tradition and the challenge to the time-honoured privileging of the author, have resulted in a whole new way of looking at the question of influence and of relationships between texts. This process has been aided by the enhanced appreciation of Senecan drama by classicists since the 1970's. With the resurgence of interest in Senecan tragedy, the plays have increasingly been studied as drama on their own terms, rather than as bad "Greek" plays or as "Silver" (and so, by implication, inferior) Latin declamatory drama. Scholars have begun to acknowledge the power of much of Senecan tragedy and to explore its unique characteristics without the prejudice which tainted so much writing on the dramas in the last century and the early part of this one.

The search for verbal reminiscences between Seneca and Shakespeare although not altogether abandoned, has been subordinated to an interest in wider issues. Attention has turned to the Senecan nature of the rhetoric in so much English Renaissance drama and has probed the obvious surface similarities in order to articulate the concept of private selfhood that underlies it, investigate the passions

$7 \quad$ Altman 1978; Braden 1985; Martindale 1990; Miola 1992. 
expressed by it, understand the Stoicism which underpins it, and explore the concern with the supernatural by which it is characterised. Interest in Shakespeare's use of Seneca as "a source" for specific speeches, situations, and characters has given way to an investigation of Shakespeare's debt to Seneca in terms of infrastructureatmosphere, internal design, imagery, reformulated conventions, heroic ideals, religious and philosophical thought-in short, to a tracing of what T.S. Eliot called "the penetration of Senecan sensibility". It has been recognised that "Shakespeare's use of Seneca ... may be ... more a matter of glancingly rapid effects than of a laborious working out of correspondences" (Jones 1977:272). The "empire of Senecan influence" has by no means been destroyed-simply reassessed and diversified.

\section{BIBLIOGRAPHY}

Altman, J B 1978. The Tudor play of mind: Rhetorical enquiry and the development of Elizabethan drama. Berkeley, Los Angeles \& London: California University Press.

Baker, H 1939. Induction to tragedy: A study in a development of form in Gorboduc, the Spanish Tragedy and Titus Andronicus. Louisiana: Louisiana State University Press.

Baldwin, T W 1944. William Shakespeare's small Latine and lesse Greeke. 2 vols. Urbana, Illinois: University of Illinois Press.

Braden, G 1985. Renaissance tragedy and the Senecan tradition: Anger's privilege. New Haven \& London: Yale University Press.

Charlton, H B [1921] 1974. The Senecan tradition in renaissance tragedy. Reprint. Manchester: Manchester University Press.

Costa, C D N 1975. Polonius, Seneca, and the Elizabethans. PCPS ns. 21:33-41.

Cunliffe, J W [1893] 1965. The influence of Seneca on Elizabethan tragedy. Reprint. Connecticut: Archon Books.

Feuillerat, A (ed.) 1923. The complete works of Sir Philip Sydney, vol. 3. Cambridge: Cambridge University Press.

Hunter, G K 1967. Seneca and the Elizabethans: A case-study in "influence". Shakespeare Survey 20:17-26.

Hunter, G K 1974. Seneca and English tragedy. In Costa, C D N (ed), Seneca. London \& Boston: Routledge and Kegan Paul.

Jones, E 1977. The origins of Shakespeare. Oxford: Clarendon Press.

Jonson, B 1623. To the memory of my beloved, the author Mr. William Shakespeare and what he hath left us. In Herford, C H and Simpson, P and E (eds), Ben Jonson, vol. 3. Oxford: Clarendon Press, 1947.

Kiefer, F 1978. Seneca's influence on Elizabethan tragedy: An annotated bibliography. Research opportunities in Renaissance drama 21:17-34. Supplement 1985 in Research opportunities in Renaissance drama 28:129-142. Martindale, C \& M 1990. Shakespeare and the uses of antiquity. London \& New York: Routledge. 
Miola, R S 1992. Shakespeare and classical tragedy. Oxford: Clarendon Press. Scaliger, J C [1561] 1964. Poetices libri septem. Reprint. Stuttgart: Frommann. Spearing, E M 1912. The Elizabethan translations of Seneca's tragedies. Cambridge: W. Heffer and Sons Ltd.

Tarrant, R J (ed) 1985. Seneca's Thyestes. American Philological Association Textbook Series Number 11. Atlanta, Georgia: Scholars Press.

Whitaker, V K 1969. Shakespeare's use of learning. California: University of California Press. 